\title{
Male Pseudohermaphroditism
}

\section{Due to $17 \alpha$-Hydroxylase Deficiency}

\author{
Maria I. New with the technical assistance of Laddawan SuvannakuL \\ From the Department of Pediatrics, The New York Hospital-Cornell Medical \\ Center, New York, New York 10021
}

A в S TRACT This is the first report of a male with $17 \alpha$-hydroxylase deficiency resulting in male pseudohermaphroditism, ambiguous external genitalia, absence of male secondary sexual characteristics, and gynecomastia at puberty. Diagnosis was based on extensive studies of steroid metabolism including the following: low urinary excretion of 17-ketosteroids and 17-hydroxycorticoids which did not increase after $\mathrm{ACTH}$; no response of very low plasma testosterone and dehydroepiandrosterone to adrenocorticotropin (ACTH) or chorionic gonadotropin; and low urinary aldosterone and plasma renin which increased after dexamethasone. Secretion rates of 17-hydroxylated steroids, cortisol (F) and 11-desoxycortisol (S), were very low while desoxycorticosterone (DOC) and corticosterone (B) secretion rates were increased sevenfold. Results expressed as milligrams per meter squared per day were as follows: F, 1.3 ; S, 0.023 ; DOC, 0.35 ; and $\mathrm{B}, 16$ (mean normal values were $\mathrm{F}, 7.5 ; \mathrm{S}, 0.26 ; \mathrm{DOC}, 0.055$, and $\mathrm{B}, 2.2)$. Plasma gonadotropins were markedly increased (FSH, 106; LH, $364 \mathrm{mIU} / \mathrm{ml}$ ). Testicular biopsies revealed interstitial-cell hyperplasia and early spermatogenesis. Karyotype was 46/XY. Pedigree showed no other affected member. At laparotomy ovaries, uterus, and fallopian tubes were absent, vas deferens was incomplete, and prostate was present. External genitalia consisted of small phallus, bifid scrotum, third-degree hypospadias, and small vagina. At puberty there was no growth of body hair or phallic enlargement. Biopsy of marked gynecomastia showed both ducts and acini. Testosterone administration produced virilization. Sexual ambiguity demonstrates strong dependence of external genitalia on androgens for male differentiation. Suppression of Müllerian structures occurred despite female levels of testosterone indicating this step in male

Dr. New was the recipient of Career Scientist Award of the Health Research Council of the City of New York under Contract I 481.

Received for publication 19 February 1970 and in revised form 26 May 1970. differentiation is not testosterone dependent. Pubertal breast development in this male supports the concept of femaleness during ontogeny unless counteracted by male factors. Diagnosis of other adrenocortical enzymatic deficiencies is excluded by the steroidal studies. The clinical response to testosterone excludes testicular feminization. Deficiency of 17 -hydroxylation must be added to the cause of male pseudohermaphroditism.

\section{INTRODUCTION}

Since the report by Biglieri, Herron, and Brust of $17 \alpha-$ hydroxylase deficiency in a female (1), there have been three subsequent females described with the syndrome of hypertension, primary amenorrhea, and sexual infantilism due to defective 17 -hydroxylation $(2,3)$ of steroids.

This is the first report of a male with $17 \alpha$-hydroxylase deficiency which resulted in male pseudohermaphroditism, ambiguous external genitalia, absence of male secondary sexual characteristics, and prominent breast development at puberty. Unlike the previously reported females, this male did not manifest severe hypertension or hypokalemia. Deficiency of an enzyme necessary for synthesis of testosterone and estrogen in the female resulted in a normal phenotype while in the male the phenotype was markedly altered. The role of estrogens and androgens in embryological differentiation of the human male external and internal genitalia and in the production of secondary sexual characteristics is elucidated by this case.

\section{METHODS}

Secretion rates of cortisol (F), 11-desoxycortisol (S), corticosterone (B), and 11-desoxycorticosterone (DOC)

\footnotetext{
${ }^{1}$ The following compounds and their trivial names and abbreviations are used: 17,21-dihydroxy-pregn-4-ene 3,20 dione (11-desoxycortisol; compound $\mathrm{S}$ ); $3 \alpha, 17,20$-trihydroxy-5 $\beta$-pregnane (pregnanetriol); and $9 \alpha$-fluoro-16 $\alpha$ methyl-11 $\beta, 17 \alpha, 21$-trihydroxypregn-1,4-diene-3,20-dione (dexamethasone; Decadron).
} 
were measured by the method of New, Seaman, and Peterson (4). Urinary 17-ketosteroids, 17-hydroxycorticosteroids, pregnanetriol, aldosterone, and plasma 17-hydroxycorticoids were measured by previously reported methods (5). Plasma androgens were determined by a double isotope dilution derivative technique (6). Urinary estrogens were determined by the method of Brown, Bulbrook, and Greenwood (7), as modified by Beling (8) and urinary pregnanediol by the method of Klopper, Michie, and Brown (9). Plasma luteinizing hormone $(\mathrm{LH})$ and follicle-stimulating hormone (FSH) were determined by a radioimmunoassay $(10)$. The urinary 17 -ketosteroids were partitioned by a single isotope dilution technique utilizing hot acid hydrolysis, separation of steroids by paper chromatography, and quantitation of the separate eluates by the Zimmermann reaction (5).

The various periods of study described in the results were as follows: base line-no medications; i.v. ACTH-40 U of $\mathrm{ACTH}$ intravenously daily; metyrapone $-3 \mathrm{~g}$ of metyrapone p.o. daily for 3 days; Decadron-8 $\mathrm{mg}$ of dexamethasone p.o. daily for 3 days; Decadron + CGT $-8 \mathrm{mg}$ of dexamethasone p.o. + human chorionic gonadotropin, $5000 \mathrm{U}$ intramuscularly, daily for 3 days; and testosterone-injection of 400 $\mathrm{mg}$ of testosterone enanthate intramuscularly once.

Case report. This $24 \mathrm{yr}$ old male pseudohermaphrodite was admitted for mastectomy. He was born with ambiguous genitalia and the sex assignment was uncertain until his first medical investigation at age 20 months when he was definitely considered male. At that age his height $(90 \mathrm{~cm})$ and weight $(14.5 \mathrm{~kg})$ and blood pressure were normal. His genitalia were described as follows: "the labia majora or bifid scrotum contain oval shaped bodies (testes); that on the right is descended and on the left is at the upper pole of labium. There is a large prepuce and rudimentary penis. A urethral groove is visible on the under surface which is divided into two halves. At the posterior end of this groove is an opening leading to the bladder." $\mathrm{His}$ bone age and urinary 17-ketosteroid excretion were normal. Upon cystoscopy at 21 months, a $1.5 \mathrm{~cm}$ vagina was visualized. The urethral meatus was located in the vagina. No cervix was observed. The urethra was described as female in type. Exploratory laparotomy at 22 months reported "no female adnexa." The diagnosis was male pseudohermaphroditism. $\mathrm{He}$ was thereafter reared as a male.

At $3 \frac{1}{2} \mathrm{yr}$ of age he weighed $18.7 \mathrm{~kg}$ and his height was 103 $\mathrm{cm}$. A biopsy of the right testicle revealed an infantile testis and a normal epididymis. Exploration of the left inguinal canal did not locate the left testicle. Microscopic examination of the right testicular biopsy showed tubules lined by columnar epithelium which appeared to be inactive. There were no mitotic figures, spermatocytes, or sperm seen. The interstitial tissue was minimally increased and consisted of closely packed fibrous tissue but no increase in Leydig cells. At the age of $3 \frac{1}{2}$ he was treated with methyl testosterone $5 \mathrm{mg}$ p.o. daily and $5 \mathrm{mg} / \mathrm{g}$ of testosterone ointment by inunction to the genital area for 2 months. The penis increased from 2.5 to $3.2 \mathrm{~cm}$ in length. An intravenous pyelogram at this time demonstrated normal renal function but an unusual bladder neck. Over the next $5 \mathrm{yr}$ he had multiple urologic operations to release the chordee, lengthen the penis, and bring the urethra to the mid-shaft of the penis. $\mathrm{He}$ next presented himself at the age of 16 because he had developed marked gynecomastia over the previous $2 \mathrm{yr}$. At that time he manifested no secondary sex characteristics except gynecomastia. He had no pubic, axillary, or facial hair. A prostate was palpated. A small right testis was in the scrotum and a mass was felt in the left inguinal canal. Urinary 17 -ketosteroid excretion was $14 \mathrm{mg} / 24 \mathrm{hr}$ (normal for outside laboratory $15-20)$; 17-hydroxycorticoid excretion was $2.3 \mathrm{mg} / 24 \mathrm{hr}$ (normal for outside laboratory 2-4). Karyotype was reported as $46 / \mathrm{XY}$ and a male chromatin pattern was observed on buccal smear. Serum electrolytes were normal (K, $4.1 \mathrm{mEq} /$ liter $)$. Repeat testicular biopsies were performed at age 16 which revealed the same microscopic findings bilaterally. There was mild tubular atrophy with increased space between tubules and basement membrane thickening. Tubules showed decreased spermatozoa and were lined almost completely with Sertoli cells. There was a relative increase in Leydig cells. The microscopic diagnosis was atrophy of the right and left testes. When the patient was $20 \mathrm{yr}$ of age, a prostate was palpated and the patient claimed to have normal libido but no ejaculation or orgasm. His voice was high-pitched, he still had no facial, axillary, or body hair, no temporal hair recession, and gynecomastia was marked. Height was 68 inches (pubis to crown, $31 \frac{1}{4}$ inches, and pubis to floor, $36 \frac{1}{4}$ inches). A bone age was normal and the proximal epiphyses of the fibulae were fused.

$\mathrm{He}$ was admitted for the first time to The New York Hospital at $24 \mathrm{yr}$ of age for mastectomy. At this time he had marked gynecomastia (see Fig. 1), hypospadias, chordee, hypoplasia of the scrotum, empiy left scrotum, and a small right gonad. His height was 68 inches and weight $206 \mathrm{lb}$. The blood pressure was only slightly elevats.' (150-130/ 90-60). He was markedly obese and had a eunuchoid habitus. He claimed to have erections and sexual intercourse but no ejaculation. Enuresis was common. His voice was high-pitched, there was no recession of temporal hair line, skin was very smooth, and there was no facial hair, seborrhea, or acne. He never had shaved. Repeated cystoscopy confirmed the presence of a vaginal utricle $1.5 \mathrm{~cm}$ from the bladder neck in the floor if the urethra. The $2 \times 3$ $\mathrm{cm}$ utricle could be filled with water and readily emptied with pressure via a $2 \mathrm{~mm}$ opening into thi = ro: ally construciei urethra. A retrograde and voicing cystogram demonstrated an irregular distal urethra and a bulbous dilation of the mid-portion of the urethra. Bone age was norma! (Fig. 2).

At this point he was studied extensively from an endocrine viewpoint as indicated below. Random fasting growth hormone level was $1.9 \mathrm{~m} \mu \mathrm{g} / \mathrm{ml}$ (normal 0-8). A mastectomy was performed and the microscopic sections showed an unusual lobular pattern of acini (Fig. 3). He had a smooth operative and postoperative course without steroid treatment. Postoperatively he was treated with testosterone enanthate $400 \mathrm{mg}$ intramuscularly and subsequently testosterone propionate $25 \mathrm{mg}$ intramuscularly every 2 wk. Within $6 \mathrm{wk}$ he manifested the following signs of virilization: deepening of voice, seborrhea and very slight acne, pubic hair and facial hair requiring him to shave weekly. He claimed improved muscular strength. In addition body hair on arms and legs increased. The size of the phallus after 2 months of treatment with testosterone had not changed. Family history revealed no other affected member.

Review of testicular biopsies confirmed histological diagnosis of infantile testes at age 2 . At age 16 the presence of spermatocytes and marked interstitial-cell hyperplasia was confirmed (Fig. 4). A repeat karyotype was $46 / \mathrm{XY}$. 


\section{RESULTS}

Urinary excretion of metabolites of steroidal hormones (Table I). The daily urinary 17-ketosteroid excretion was low for an adult male and the response to ACTH was minimal. The 17-hydroxycorticoid excretion doubled with ACTH but showed no greater increase with metyrapone. At no period before treatment with testosterone did the urinary 17-ketosteroid excretion or the 17-hydroxycorticoid excretion rise to adult male levels.
Although the urinary 17 -hydroxycorticoids suppressed briskly with $2 \mathrm{mg}$ of dexamethasone, the 17-ketosteroid values decreased only slightly. With the maintenance of adrenal suppression, chorionic gonadotropin did not increase the 17 -ketosteroid excretion. Treatment with testosterone increased 17-ketosteroid excretion while 17hydroxycorticoid excretion remained low. A partition of the urinary 17-ketosteroid on the day of ACTH administration showed an etiocholanolone excretion of $2.1 \mathrm{mg}$,

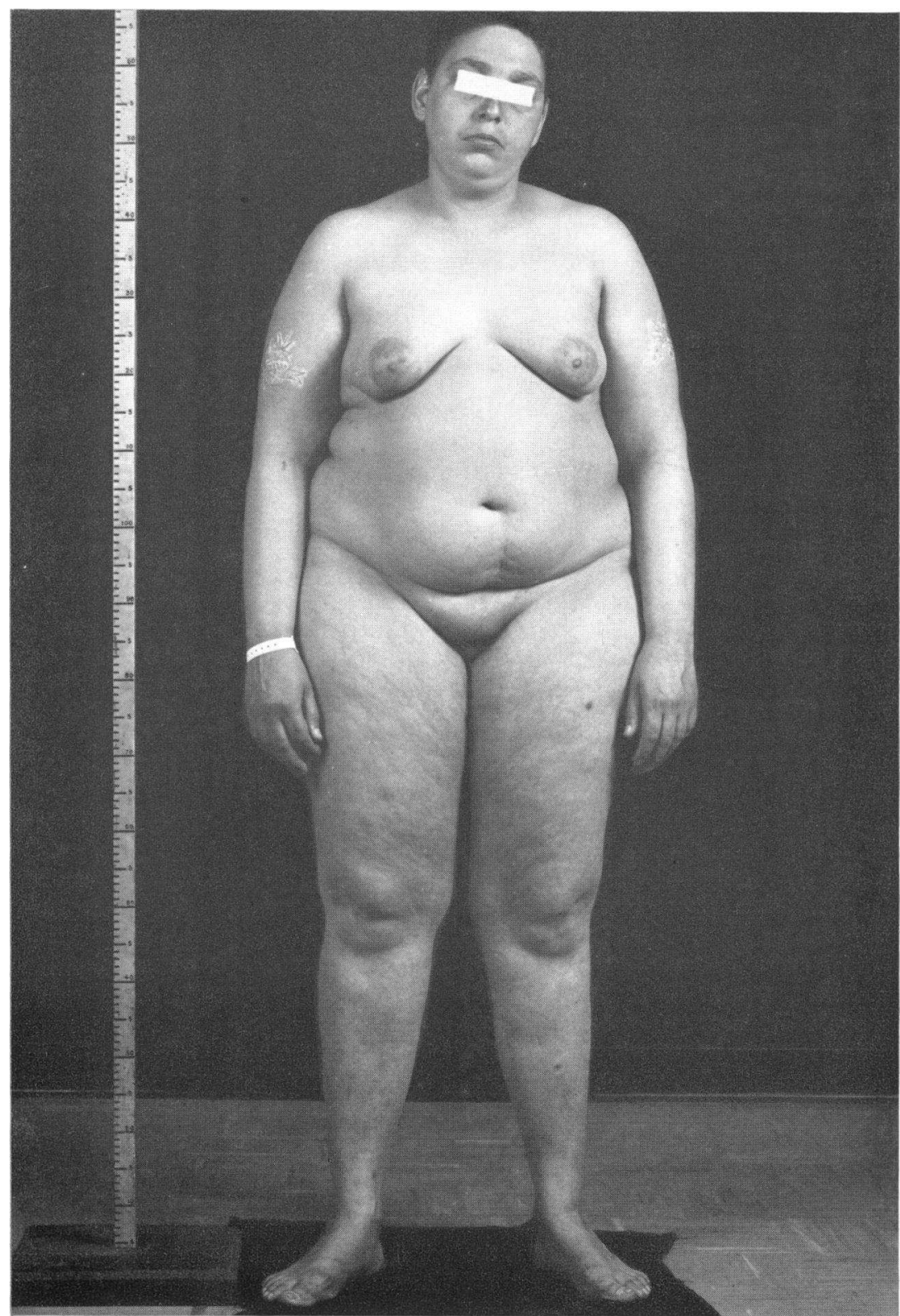

FIGURE 1 17-Hydroxylase defect resulting in male pseudohermaphroditism with prominent breast development and absence of virilizing signs at puberty. Note eunuchoid habitus, absence of recession of hairline, and hairlessness. 


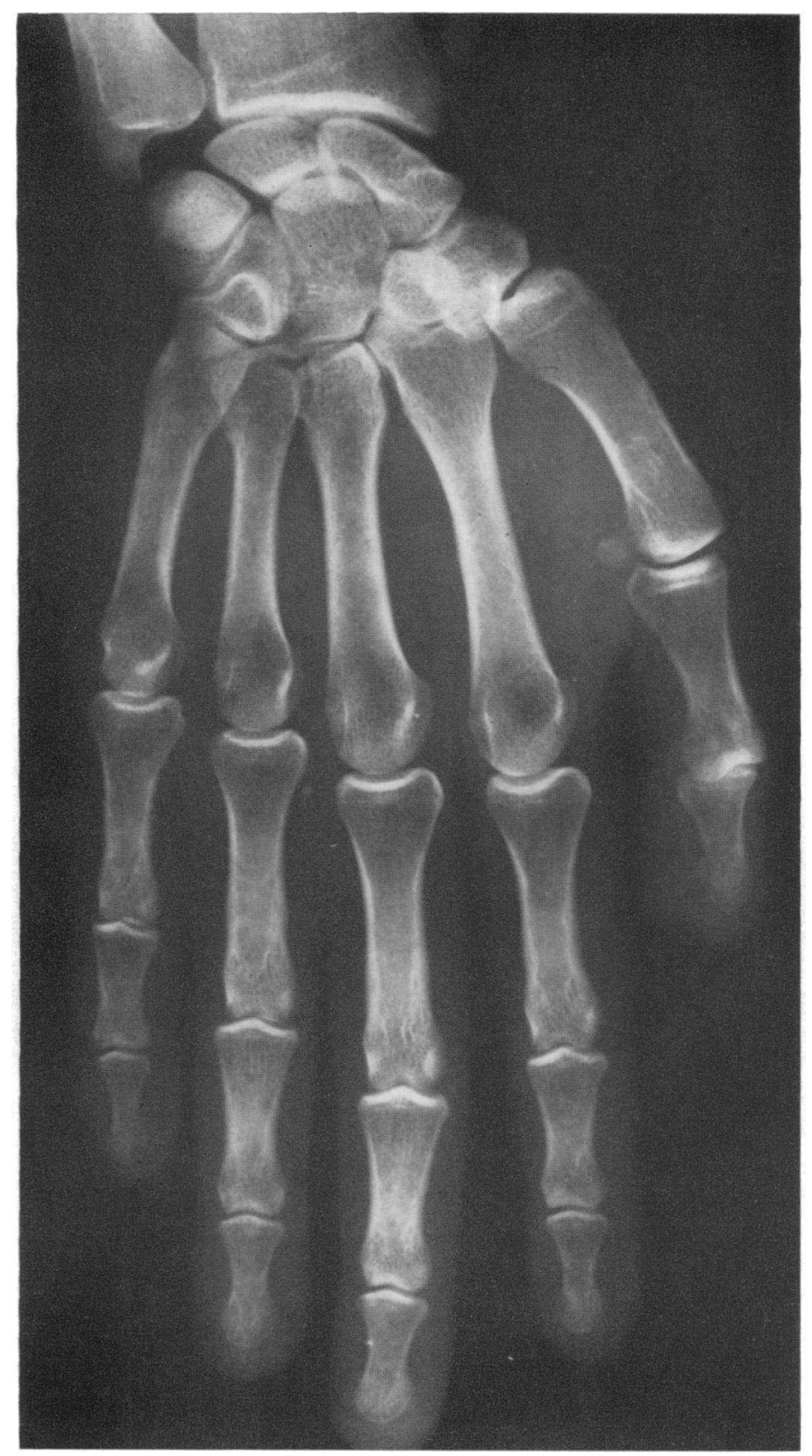

FigURE 2 Wrist film demonstrating fusion of all epiphyses of metacarpals and distal ulna and radius, despite marked deficiency of androgens and estrogens.

androsterone $2.5 \mathrm{mg}$, and dehydroepiandrosterone of $1.9 \mathrm{mg}$. The total 17-ketosteroid excretion on that day was $6.6 \mathrm{mg}$.

Pregnanetriol excretion was slightly increased. This was determined by an unpublished single isotope dilution technique and then rechecked by a double isotope dilution derivative technique (11). The level of pregnanetriol excretion varied very little with either stimula- tion by ACTH or chorionic gonadotropin or with suppression by dexamethasone or testosterone (see Table I).

By the method used, the total excretion of estrone $\left(E_{1}\right)$, estradiol $\left(E_{2}\right)$, and estriol $\left(E_{3}\right)$ is $5-10 \mu \mathrm{g}$ in normal males. Estrogen excretion in this patient was very low. $E_{2}$ was $1.1 \mu \mathrm{g} /$ day. $E_{1}$ and $E_{3}$ were undetectable.

This patient excreted $0.29 \mathrm{mg}$ of pregnanediol in 24 hr. Although few determinations of pregnanediol in 


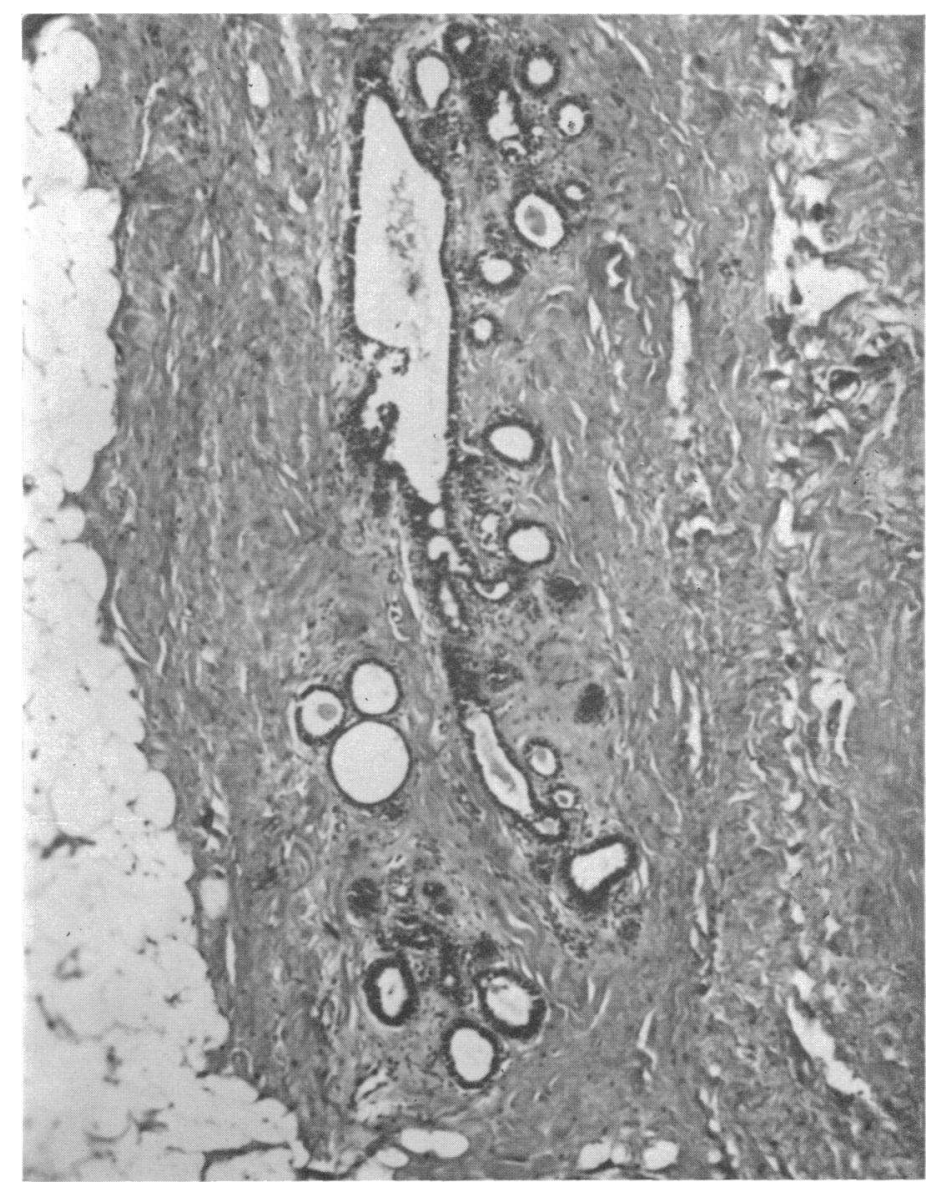

FigUre 3 Histology of breast tissue demonstrating both ductal and acinar development.

male urine have been reported, this level does not appear to be elevated. Excretion rates in males have been previously reported as $0.32-0.88 \mathrm{mg} /$ day (12) ; $1.1 \mathrm{mg} /$ day (13), and $0.7 \mathrm{mg} /$ day (14).

Plasma hormones (Table I). The plasma 17-hydroxycorticoids were initially at the lower limit of normal and showed no diurnal variation. There was no rise of plasma 17-hydroxycorticoids with ACTH administration; however, the pre-ACTH concentration was higher than previous values. The plasma testosterone levels were repeatedly in the female range and below the normal adult male range (6). Neither ACTH nor chorionic gonadotropin administration caused an increase in the plasma testosterone. Dexamethasone did not suppress the already low levels of testosterone. The plasma dehydroepiandrosterone (DEA) was below normal female or male levels (6). Plasma gonadotropins were very high (FSH 106, LH 364). Normals for this laboratory are FSH 3.9-42, LH $2.5-32 \mathrm{mIU} / \mathrm{ml}$ (10). Plasma renin initially was very low, $0.1 \mathrm{~m} \mu \mathrm{g} / \mathrm{ml}$ per $\mathrm{hr}$. Normal values in this laboratory are $2-7 \mathrm{~m} \mu \mathrm{g}$ of angiotensin gen- erated per $\mathrm{ml}$ per $\mathrm{hr}$. Plasma progesterone was 0.020 $\mu \mathrm{g} / 100 \mathrm{ml}^{2}$ Normal values for a female in the follicular phase are $0.020-0.100 \mu \mathrm{g} / 100 \mathrm{ml}$. Normal male levels are very low. Plasma 17-hydroxyprogesterone was 0.091 $\mu \mathrm{g} / 100 \mathrm{ml}^{2}$ and 17 -hydroxy- $\Delta-5$-pregnenolone was 0.200 $\mu \mathrm{g} / 100 \mathrm{ml} .^{2}$ Both values were considered to be within the normal range.

Secretion rates of cortisol $(F)$, corticosterone $(B)$, desoxycorticosterone (DOC), desoxycortisol $(S)$, and aldosterone (aldo) (Table II). The secretion rates of $\mathrm{F}, \mathrm{S}$, and aldo were very low whereas the secretion rates of B and DOC were 7-8 times normal (4).

Metabolic balance studies (Fig. 5). The sodium and potassium balance as determined by dietary intake and urinary excretion are depicted in Fig. 5. The blood pressure was never very elevated. The highest diastolic blood pressure was $100 \mathrm{~mm}$. No single period of study produced a consistent change in blood pressure; rather the values

\footnotetext{
${ }^{2}$ We are grateful to Dr. Mortimer Lipsett for carrying out these determinations. Normal values are those given by Dr. Lipsett for his laboratory.
}

\section{M. I. New}


were erratic throughout. ACTH administration induced the expected acute rise in aldosterone excretion but no other significant change. Metyrapone produced a marked sodium retention but no kaliuresis while aldosterone excretion returned to low control levels. This suggested that a hormone other than aldosterone was responsible for the sodium retention. In contrast dexamethasone caused a marked natriuresis without significant kaliuresis, while the aldosterone excretion remained at the previously low level. Toward the end of the period of the treatment with dexamethasone when human chorionic gonadotropin was added to the therapy, aldosterone excretion began to increase and continued to increase even after dexamethasone treatment was discontinued and one dose of testosterone enanthate was administered. As aldosterone excretion increased, sodium balance was gradually restored and potassium excretion increased to meet intake levels. The serum $\mathrm{Na}$ and $\mathrm{K}$ were normal at the beginning and end of the study.

The 17-ketosteroid excretion remained low throughout except for the period after testosterone therapy.

\section{DISCUSSION}

A. Laboratory data. The low urinary excretion of 17 ketosteroids, 17-hydroxycorticoids, aldosterone, and estrogens and the low plasma testosterone and high plasma gonadotropins present in this patient are similar to the findings in the females reported with $17 \alpha$-hydroxylase deficiency (1-3). The low plasma 17-hydroxycorticoids and the lack of response to ACTH were reported by Goldsmith, Solomon, and Horton (2) (Table III).
The slightly elevated urinary pregnanetriol is surprising since other 17-hydroxylated precursors of cortisol are markedly decreased. The presence rather than absence of plasma 17-hydroxyprogesterone and 17-hydroxy- $\Delta$-5-pregnenolone suggests that the 17 -hydroxylase deficiency is partial. The pregnanediol and plasma progesterone were curiously not increased despite an increased production of other aldosterone precursors, e.g., DOC and B. Perhaps the adrenal precursor progesterone is rapidly utilized for synthesis of B and DOC in this patient and is not secreted freely into the circulation. In the patient of Biglieri et al. (1) the urinary pregnanediol and plasma progesterone were not increased while in the case of Goldsmith et al. (2) they were markedly increased (Table III).

Unlike the data on the patient of Biglieri et al. (1) in whom the $17 \alpha$-hydroxylase defect was very severe, the laboratory data on this male patient suggest a partial $17 \alpha$-hydroxylase deficiency. The degree of defect is comparable to that in patients reported by Goldsmith et al. (2) and Mallin (3). This statement is based on a similar elevation of the secretion rates of $\mathrm{B}$ and $\mathrm{DOC}$ and $\mathrm{a}$ similar depression in the secretion of $\mathrm{F}, \mathrm{S}$, and aldosterone (Table III). The impairment in androgen synthesis appears to be more marked than that in cortisol synthesis. The plasma testosterone did not respond either to ACTH or to chorionic gonadotropin which suggests that both testis and adrenal are deficient in 17-hydroxylation. In the other form of male pseudohermaphroditism caused by an enzymatic defect, the $3 \beta$-ol-dehydrogenase deficiency, the defect occurs in the gonad and adrenal as well (15). The low plasma DEA and high DOC and

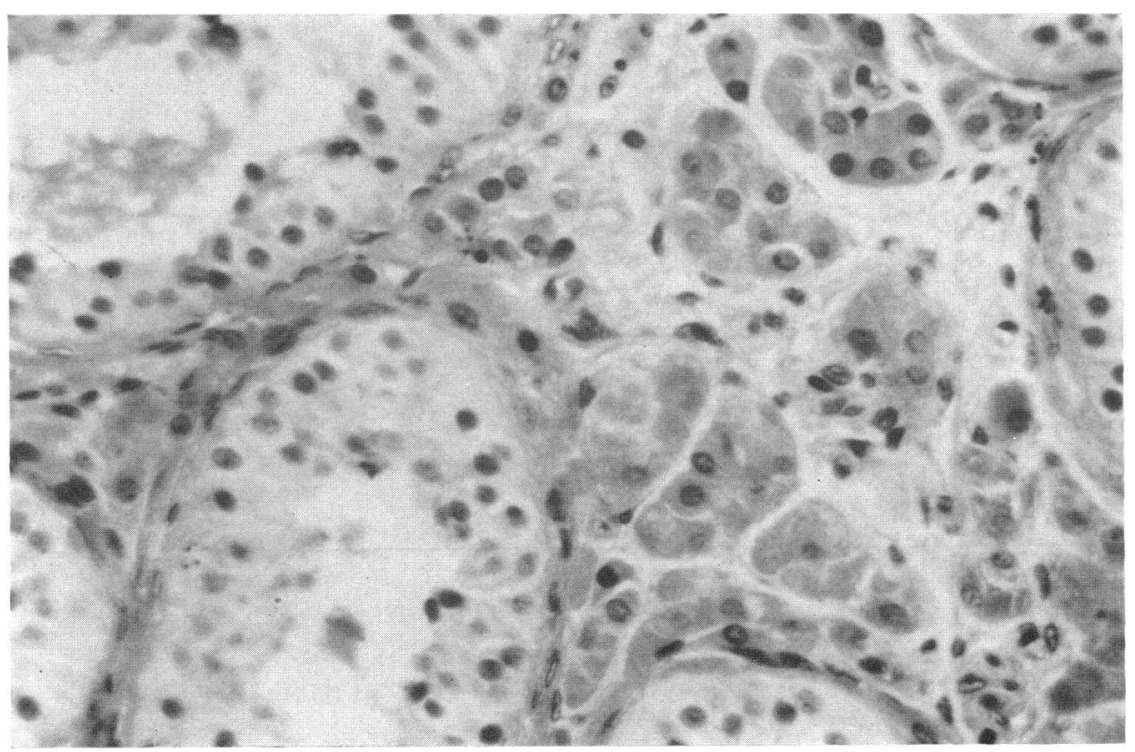

FIgURE 4 Histological section of testicular biopsy at age 16. Note Leydig cell hyperplasia and early spermatogenesis. 
TABLE I

Laboratory Studies in a Male Pseudohermaphrodite with 17 $\alpha$-Hydroxylase Defect

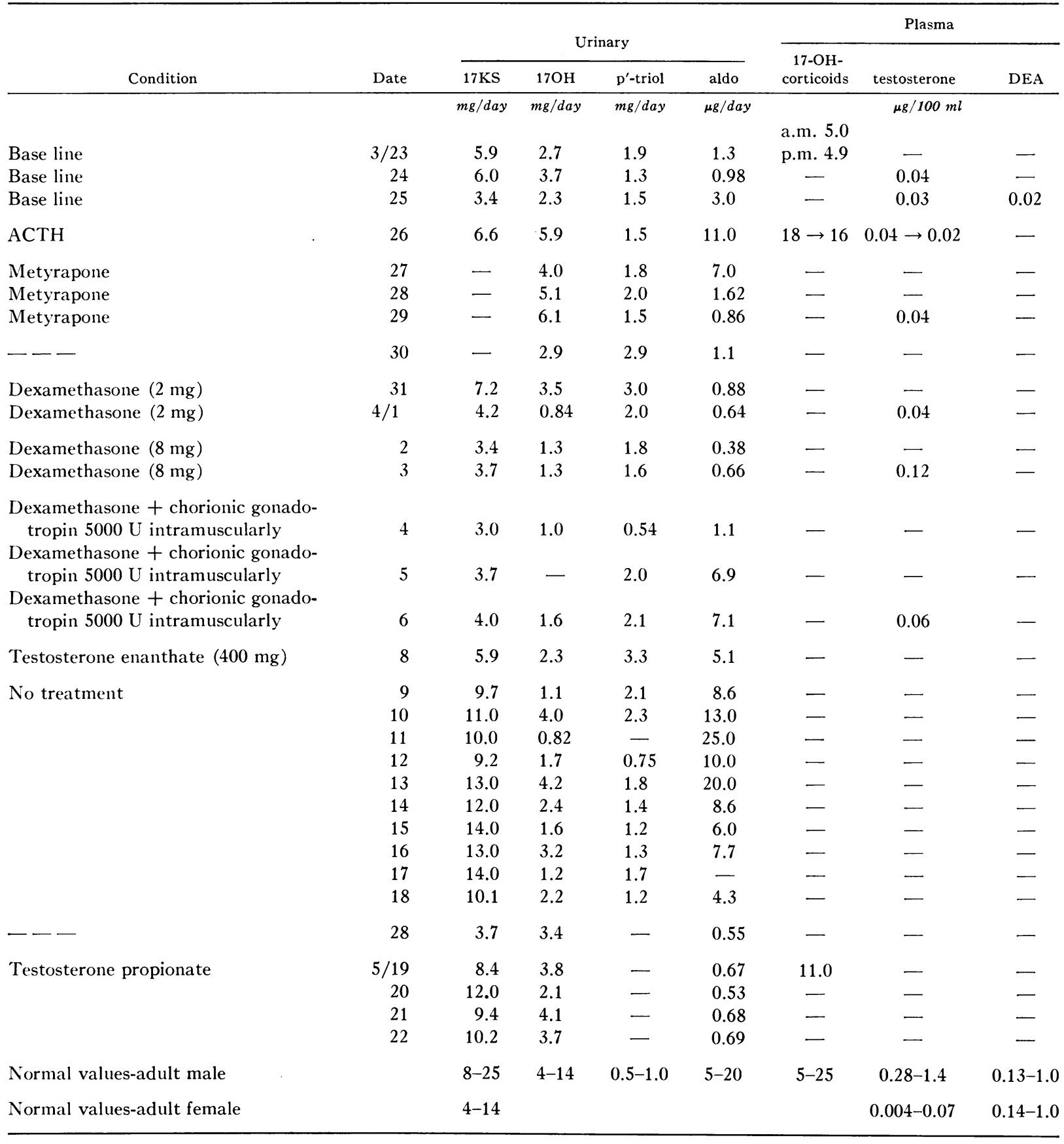

B secretion rates eliminate a $3 \beta$-ol-dehydrogenase defect as the cause of low androgen production. The overproduction of DOC is less than that reported by others, an observation which is compatible with the absence of hypokalemia or severe hypertension. Yet aldosterone secretion is largely suppressed presumably via the same mechanism proposed for the patient of Biglieri et al. (1), i.e., the excess $\mathrm{DOC}$ causes $\mathrm{Na}$ retention which suppresses renin and secondarily aldosterone production. This is supported by the return to normal or even increased levels of aldosterone after dexamethasone administration. With this treatment, DOC secretion is 
TABLE II

Secretion Rate Studies

\begin{tabular}{|c|c|c|c|c|c|c|c|c|c|c|c|c|c|}
\hline \multirow[t]{2}{*}{ Patient } & \multirow[t]{2}{*}{ Age } & \multicolumn{2}{|c|}{ Cortisol } & \multicolumn{2}{|c|}{ Corticosterone } & \multicolumn{2}{|c|}{ Desoxycorticosterone } & \multicolumn{2}{|c|}{ Desoxycortisol } & \multicolumn{2}{|c|}{ Aldosterone } & \multicolumn{2}{|c|}{$\begin{array}{l}\text { Urinary } \\
\text { excretion } \\
\text { aldo } \mathrm{pH} 1\end{array}$} \\
\hline & & $m g / d a y$ & $\begin{array}{c}m g / m^{2} \\
\text { per day }\end{array}$ & $m g / d a y$ & $\begin{array}{l}m g / m^{2} \\
\text { per day }\end{array}$ & $m g / d a y$ & $\begin{array}{l}m g / m^{2} \\
\text { per day }\end{array}$ & $m g / d a y$ & $\begin{array}{l}m g / m^{2} \\
\text { per day }\end{array}$ & $m g / d a y$ & $\begin{array}{l}m g / m^{2} \\
\text { per day }\end{array}$ & $\mu g / d a y$ & $\begin{array}{c}\mu g / m^{2} \\
\text { perday }\end{array}$ \\
\hline \multicolumn{14}{|c|}{ Normal subjects } \\
\hline K.McG. & 14 & 8.3 & 5.2 & 2.2 & 1.4 & 0.046 & 0.029 & 0.23 & 0.14 & 一 & - & 15.0 & 9.4 \\
\hline H.McG. & 41 & 15.5 & 7.8 & 4.3 & 2.2 & 0.12 & 0.06 & 0.31 & 0.15 & - & - & 24.0 & 12.0 \\
\hline M.H. & 16 & 25.0 & 14.0 & 4.3 & 2.4 & 0.12 & 0.067 & 0.5 & 0.28 & 0.12 & 0.067 & 22.0 & 12.0 \\
\hline C.M. & 3 & 4.9 & 7.0 & 0.84 & 1.2 & 0.042 & 0.06 & 0.3 & 0.43 & 0.17 & 0.24 & 11.0 & 16.0 \\
\hline C.P. & 8 & 5.8 & 5.8 & 1.5 & 1.5 & 0.079 & 0.079 & 0.48 & 0.48 & 一 & - & - & - \\
\hline C.B. & 14 & 19.0 & 11.0 & 5.9 & 3.5 & 0.10 & 0.06 & 0.28 & 0.16 & 0.078 & 0.046 & 13.0 & 7.4 \\
\hline J.P. & 22 & 6.7 & 3.5 & 5.5 & 2.9 & 0.034 & 0.019 & 0.51 & 0.27 & 0.38 & 0.22 & 19.0 & 10.0 \\
\hline T.W. & 20 & 17.2 & 8.5 & 7.3 & 3.7 & 0.12 & 0.06 & 0.3 & 0.15 & - & - & 15.0 & 7.3 \\
\hline T.W.' & 21 & 14.5 & 7.3 & 4.3 & 2.2 & 0.073 & 0.037 & 0.42 & 0.21 & 0.16 & 0.082 & 18.0 & 9.2 \\
\hline M.McG. & 13 & 5.7 & 3.6 & 1.7 & 1.1 & 0.12 & 0.075 & 0.45 & 0.28 & - & - & 12.0 & 7.5 \\
\hline R.W. & 0.5 & 3.4 & 8.5 & 一 & - & - & - & - & - & - & - & - & - \\
\hline Mean of & mals & 11.5 & 7.5 & 3.8 & 2.2 & 0.085 & 0.055 & 0.38 & 0.26 & 0.18 & 0.13 & 17.0 & 10.1 \\
\hline \multicolumn{14}{|c|}{ Male with $17 \alpha$-hydroxylase deficiency } \\
\hline E.S. & 24 & 2.8 & 1.3 & 34.0 & 16.0 & 0.76 & 0.35 & 0.051 & 0.023 & 0.075 & 0.034 & 4.3 & 2.2 \\
\hline
\end{tabular}

diminished, renin suppression ceases, and aldosterone stimulation is permitted. If the adrenal cortex were considered as two glands-the fasciculata and the glomerulosa-such feedback effects assume a more logical sequence. The fasciculata which suffers from the 17-hydroxylase defect produces excessive DOC which is released into the circulation and causes excessive renal tubular resorption of sodium which in turn suppresses renal renin production. Thus the glomerulosa does not receive the required renin stimulation for aldosterone synthesis, and low aldosterone secretion results. Upon administration of dexamethasone, ACTH stimulation of the fasciculata is suppressed and DOC secretion diminishes permitting renin stimulation of the glomerulosa to secrete aldosterone. That DOC secretion is responsible for sodium balance is deduced from $(a)$ the positive $\mathrm{Na}$ balance with very low aldosterone excretion and low plasma renin, $(b)$ the failure to observe $\mathrm{Na}$ diuresis with metyrapone despite a low aldosterone excretion, and $(c)$ when dexamethasone is administered there is profound sodium loss 5 days before a change in aldosterone. Later after prolonged treatment with dexamethamethasone, the aldosterone increases. possibly via the mechanism described above. This increase persists for some time after dexamethasone treatment is discontinued and then vanishes as evidenced by the return to a low value on $4 / 28$. (Fig. 5 ).

Like the patients reported previously, this man sustained repeated anaesthesia and major surgery despite impaired cortisol secretion. Apparently, corticosterone has sufficient glucocorticoid effect to obviate the need for cortisol administration during surgery.

The absence of hypokalemia may indicate that DOC secretion is not sufficient to produce $\mathrm{K}^{+}$wasting or that an escape from the kaliuretic effect of endogenous DOC secretion has occurred. Patients with hyperaldosteronism, however, rarely show an "escape" phenomenon from the kaliuretic effect of aldosterone but commonly show escape from sodium retention effects.

This patient clearly virilized in response to testosterone treatment ruling out any suggestion of testicular feminization.

B. Male differentiation. Because the previously reported cases (1-3) of $17 \alpha$-hydroxylase deficiency have been females with absence of secondary sexual characteristics, it is of interest that the male with this enzyme deficiency manifests male pseudohermaphroditism. Indeed the enzyme defect must be added to the list of considerations in the differential diagnosis of male pseudohermaphroditism.

Federman (16) divides male differentiation into the following four steps: $(a)$ inhibition of Müllerian primordia; $(b)$ stimulation of Wolffian ducts; $(c)$ posterior migration of labioscrotal folds; and $(d)$ elongation of genital tubercle and midline fusion of the genital folds and swellings to form the penis and scrotal sacs.

Jost (17) adds the important initial step of differentiation of the gonadal primordium into testis. It would seem worthwhile to add male secondary sex characteristics at puberty to the list of steps in total male differentiation.

Familial causes of male pseudohermaphroditism have included testicular feminization and other gradations of incomplete masculine development as reported by Prader (18), Lubs, Vilar, and Bergenstal (19), Gilbert-Dreyfus, Savoie, Sébaoun, Alexandre, and Belaisch (20), and Reifenstein (21). In all of these cases the first step in masculinization was accomplished, i.e. Müllerian duct 
suppression, while there were varying degrees of incomplete Wolffian development, phallic growth, and labioscrotal and urethral development. There is ample evidence to support the theory of Jost (22-24) that the testis plays an inducer role in the Müllerian suppression and that this inducer is not testosterone (25). Further, the development of the Wolffian system apparently requires both inducer substance and androgen while external genitalia are largely dependent on androgen.

This case of $17 \alpha$-hydroxylase deficiency in the male provides confirmation to the proposal that the male inducer substance which causes Müllerian suppression is not testosterone. The patient did not have a uterus or fallopian tubes despite a marked incapacity to synthesize androgens. The presence of the epididymis suggests that some Wolffian development occurred in this patient but it was incomplete. The lack of ejaculation suggests an absence of vas deferens. External genitalia showed the least virilization and therefore give evidence for the strongest dependence on androgens for development.

The histology of the breast tissue, which was the only manifestation of puberty, demonstrated acini and ducts as in the female. The breasts cannot, therefore, be regarded as adolescent glynecomastia which only shows periductal fibrous stroma and ductal hypertrophy (26, 27 ). The control of breast development is not entirely understood but most data suggests that pituitary gonadotropins, prolactin, and estrogen combine in some way to cause breast development in the female. Except for adolescent gynecomastia, breast development in the male suggests a pathological disorder in which there is gonadal deficiency and increased gonadotropin production (28). Both conditions were present in this patient. Federman (16) suggests the possibility that in the male there is a substance produced by the fetal testis which inhibits the breast anlage. Thus the abnormal testis in

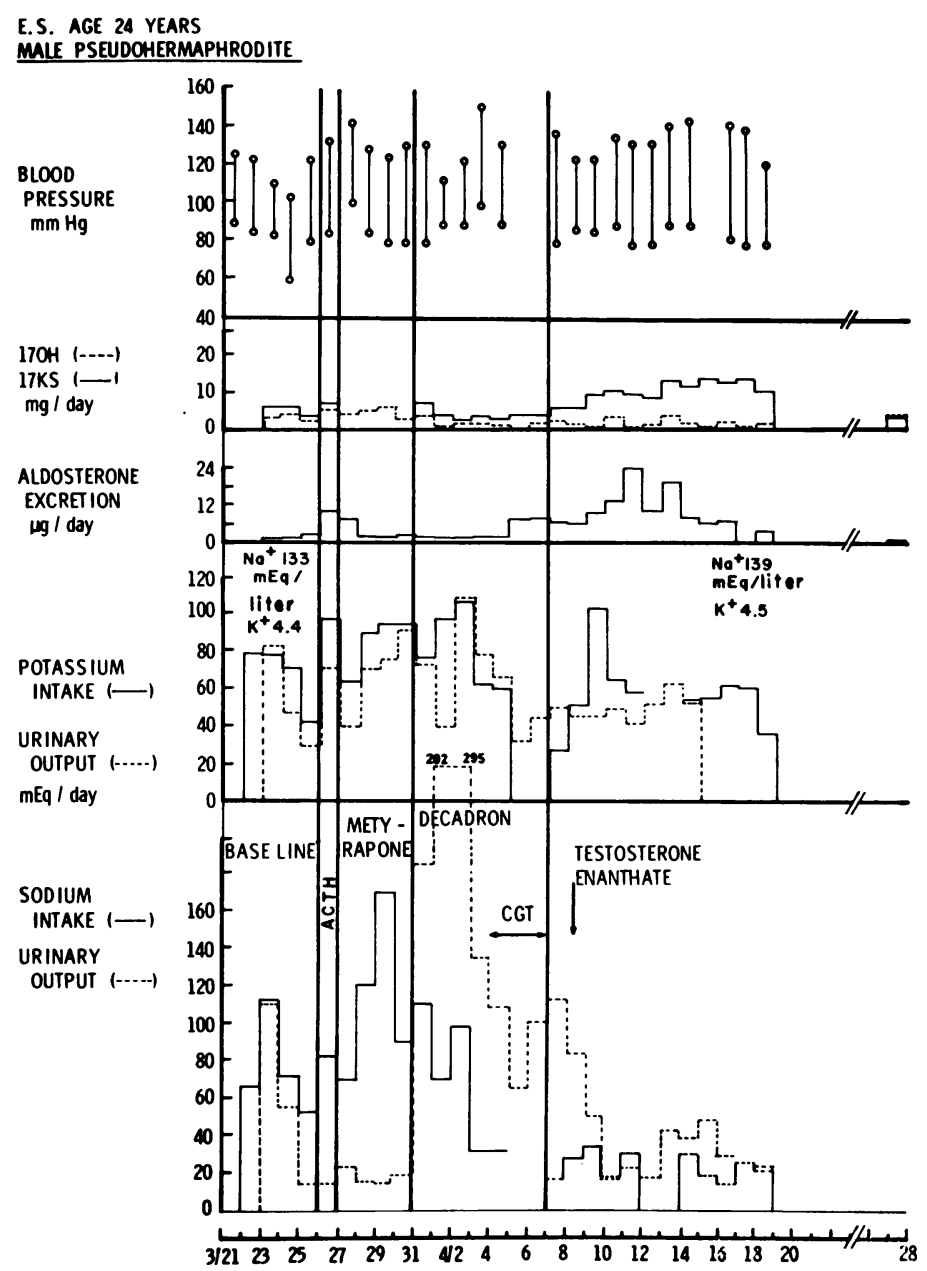

FIgURE 5 Metabolic balance of sodium and potassium correlated with various periods of therapy and hormonal measurements. 
TABLE III

Comparison of Cases with $17 \alpha$-Hydroxylase Deficiency

\begin{tabular}{|c|c|c|c|c|c|c|}
\hline \multirow[b]{3}{*}{ Sex } & \multirow{3}{*}{$\begin{array}{c}\text { Biglieri (1) } \\
\text { Female }\end{array}$} & \multirow{3}{*}{$\begin{array}{c}\text { Goldsmith (2) } \\
\text { Female }\end{array}$} & \multicolumn{2}{|c|}{ Mallin (3) } & \multirow{3}{*}{$\frac{\text { Miura (35) }}{\text { Female }}$} & \multirow{3}{*}{$\begin{array}{c}\begin{array}{c}\text { Present } \\
\text { report }\end{array} \\
\text { Male }\end{array}$} \\
\hline & & & \multicolumn{2}{|l|}{ Sibling } & & \\
\hline & & & Female & Female & & \\
\hline Age, $y r$ & 35 & 26 & 17 & $16 \frac{1}{2}$ & 17 & 24 \\
\hline Height, $\mathrm{cm}$ & 179 & 165 & 164 & - & 153 & 172 \\
\hline Weight, $k g$ & 75 & - & 44.5 & 44.5 & 43 & 106 \\
\hline Blood pressure & $220 / 140$ & $140 / 100$ & $150 / 100$ & $140 / 100$ & $180 / 100$ & $150 / 90$ \\
\hline $\begin{array}{l}\text { Female secondary sex } \\
\text { characteristics }\end{array}$ & Absent & Absent & Absent & Absent & Present & Present \\
\hline \multicolumn{7}{|l|}{ Urine } \\
\hline $\begin{array}{l}17 \mathrm{KS}, m g / \text { day } \\
17 \mathrm{OH}, m g / d a y \\
\text { Pregnanediol, } m g / \text { day } \\
\text { Pregnanetriol, } m g / \text { day } \\
\text { Aldosterone, } \mu g / \text { day } \\
\text { Estrogen }\left(\mathrm{E}_{2}\right), \mu g / \text { day }\end{array}$ & $\begin{array}{c}5.0 \\
0.0 \\
2.0-11.0 \\
- \\
<1.0 \\
<0.2\end{array}$ & $\begin{array}{c}8.0 \\
1.6 \\
21.0 \\
0 \\
1.0\end{array}$ & $\begin{array}{l}1.5 \\
0.7 \\
- \\
- \\
0.5 \\
-\end{array}$ & $\begin{array}{l}1.1 \\
0.7 \\
- \\
-\overline{0.5} \\
-\end{array}$ & $\begin{array}{l}0.9-2.8 \\
1.8-3.4 \\
17,3.8 \\
0.2,0.1 \\
\overline{23.0}\end{array}$ & $\begin{array}{l}5.9 \\
2.7 \\
0.29 \\
1.9 \\
1.3 \\
0.11\end{array}$ \\
\hline Serum $\mathrm{K}, m E q /$ liter & 2.7 & $3.2-3.6$ & 2.8 & 3.1 & $3.0-3.6$ & 4.3 \\
\hline \multicolumn{7}{|l|}{ Plasma* } \\
\hline $\begin{array}{l}17 \mathrm{OH}, \mu \mathrm{g} / 100 \mathrm{ml} \\
\text { Testosterone, } \mu \mathrm{g} / 100 \mathrm{ml} \\
\text { Progesterone, } \mu \mathrm{g} / 100 \mathrm{ml} \\
\quad \text { Normal value }\end{array}$ & $\begin{array}{l}0 \\
0.014 \\
0.21 \\
0.11-1.0\end{array}$ & $\begin{array}{c}7.0 \\
<0.01 \\
2.5\end{array}$ & - & - & - & $\begin{array}{r}5,4.9 \\
0.04 \\
0.02 \\
0.02-0.1\end{array}$ \\
\hline $\begin{array}{l}\mathrm{FSH}, m I U / m l \\
\mathrm{LH}, m I U / m l\end{array}$ & 138 & 72 & - & - & $\overline{-}$ & $\begin{array}{l}106 \\
364\end{array}$ \\
\hline $\begin{array}{l}\mathrm{GH}, m \mu g / m l \\
\text { Renin }(\mathrm{m} \mu \mathrm{g} \text { of angiotensin }\end{array}$ & 0.5 & - & - & - & - & 1.9 \\
\hline generated per $\mathrm{ml}$ per $\mathrm{hr}$ ) & 0 & 0 & - & - & - & 0.1 \\
\hline \multicolumn{7}{|l|}{ Secretion rates, $\ddagger m g / d a y$} \\
\hline $\begin{array}{l}\mathrm{F} \\
\mathrm{S}\end{array}$ & $\begin{array}{c}0 \\
\text { (THS } 0)\end{array}$ & $\begin{array}{c}3.0 \\
(\mathrm{THS} 0)\end{array}$ & - & - & $\begin{array}{c}6.7,4.4 \\
0.324\end{array}$ & $\begin{array}{l}2.8 \\
0.051\end{array}$ \\
\hline DOC & 4 & 1.4 & (THDOC 0.107 ) & 0.32 & 0.40 & 0.76 \\
\hline B & $112-124$ & 44.0 & (THB 2.0) & 1.7 & 15.0 & 34 \\
\hline Aldo & $0.010-0.018$ & 0.029 & - & - & 0.21 & 0.075 \\
\hline
\end{tabular}

* See text (Discussion, section B) and Table I for normal values.

$\ddagger$ Results in parentheses represent excretion rates rather than secretion rates.

male pseudohermaphroditism fails to cause this inhibition. Recent experiments lend support to Federman's hypothesis. Male rats treated in utero with an adrogen antagonist (cyproterone acetate) show female postnatal breast development (29). In our patient, estrogen excretion was very low, despite the prominent breast development. This would imply that hormonal factors at puberty other than estrogens promoted breast development or that the breast primordia were very sensitive to the small quantity of estrogen available. Neumann's experiments (29) also imply that estrogens may not play a major role in breast organogenesis since cyproterone acetate is not estrogenic. In addition there have been reports of breast hypertrophy upon DOC administration (30). Although it is an unlikely cause, this patient was exposed to high endogenous DOC secretion. The puzzling contrast to the females with $17 \alpha$-hydroxylase deficiency with virtual lack of breast development and this male with the same enzyme defect and prominent breasts is unexplained.

Other features of maturation in the male, i.e., bone age, height age, appear to have progressed normally despite the very low levels of androgens and estrogens.

The failure of body hair to grow, also noted in the patient of Biglieri et al. (1) must be in part attributable 
to the low androgens since the response to administered testosterone has been a prompt growth of body hair as well as facial and pubic hair.

The other enzyme deficiencies of steroidogenesis associated with male pseudohermaphroditism are $3 \beta$-oldehydrogenase (15) and desmolase deficiency $(31,32)$. However there are no reports of the type of puberty these children manifested largely because they have not survived into puberty. The suggestion by New and Peterson (33) that a phenotypic and genetic male with dexamethasone suppressible hyperaldosteronism might have suffered from a partial 17-hydroxylation defect has subsequently been revised. Further studies do not reveal any enzyme defect (34). In 1968 Miura et al. (35) described a young girl with hypertension which the authors attributed to a partial $17 \alpha$-hydroxylase defect. However, this patient had regular menstrual periods, excreted normal quantities of estrogens, had hyperaldosteronism and secreted normal levels of F, DOC and S. The similarities to the cases reported by Biglieri et al. (1), Goldsmith et al. (2), and Mallin (3) are a high B secretion rate, low urinary 17-ketosteroids, 17-hydroxycorticoids and pregnanetriol. The patient of Goldsmith et al. (2) also had a partial $17 \alpha$-hydroxylase deficiency as evidenced from this laboratory data. (Table III). Yet his patient manifested primary amenorrhea. Therefore it seems unlikely that the girl described by Miura et al. (35) falls into the same category of hypogonadism and hypermineralocorticoidism as the other females with $17 \alpha$-hydroxylase deficiency (1-3).

In summary, a partial enzymatic deficiency of $17 \alpha$ hydroxylase in a genetic male has resulted in male pseudohermaphroditism and puberty which manifested itself with prominent breast development. The ambiguity of external genitalia and pubertal breast development in this male support the concept of femaleness during ontogeny unless counteracted by male factors. The diagnosis can be suspected in a post-pubertal male pseudohermaphrodite whose urinary excretion of 17 ketosteroids, 17-hydroxycorticoids, aldosterone and plasma androgens are low. In prepuberty however when all these values are usually low, secretion rate measurements of $\mathrm{B}, \mathrm{DOC}, \mathrm{F}$, and $\mathrm{S}$ are necessary to document a $17 \alpha$-hydroxylase defect as the cause of male pseudohermaphroditism. The prediction by Van Wyk and Grumbach that $17 \alpha$-hydroxylase deficiency in a male would "exhibit male pseudohermaphroditism" has been verified by this report (36).

\section{ACKNOWLEDGMENTS}

I would like to thank Doctors Hortense Gandy, Brij Saxena, Carl Beling, and Ralph E. Peterson for their determinations of plasma DEA, plasma FSH and $\mathrm{LH}$, urinary estrogens, and plasma renin, respectively. I am especially grateful to
Dr. Peterson for his interest and counsel in the work-up of this patient.

This investigation was supported in part by Grants HD 72 and HE 12239 from the National Institutes of Health, U. S. Public Health Service, The American Heart Association Award 69 686, and was also aided by Grant FR 47 from the Division of General Medical Sciences, National Institutes of Health.

\section{REFERENCES}

1. Biglieri, E. G., M. A. Herron, and N. Brust. 1966. 17 Hydroxylation deficiency in man. J. Clin. Invest. 45: 1946.

2. Goldsmith, O., D. H. Solomon, and R. Horton. 1967. Hypogonadism and mineralocorticoid excess; the 17hydroxylase deficiency syndrome. N. Engl. J. Med. 277: 673.

3. Mallin, S. R. 1969. Congenital adrenal hyperplasia secondary to 17-hydroxylase deficiency; two sisters with amenorrhea, hypokalemia, hypertension, and cystic ovaries. Ann. Intern. Mcd. 70: 69.

4. New, M. I., M. P. Seaman, and R. E. Peterson. 1969. A method for the simultaneous determination of the secretion rates of cortisol, 11-desoxycortisol, corticosterone, 11-desoxycorticosterone and aldosterone. J. Clin. Endocrinol. Metab. 29: 514 .

5. New, M. I., B. Miller, and R. E. Peterson. 1966. Aldosterone excretion in normal children and in children with adrenal hyperplasia. J. Clin. Invest. 45: 412.

6. Gandy, H. M., and R. E. Peterson. 1968. Measurement of testosterone and 17-ketosteroids in plasma by the double isotope dilution derivative technique. J. Clin. Endocrinol. Metab. 28: 949.

7. Brown, J. B., R. D. Bulbrook, and F. C. Greenwood. 1957. An additional purification step for a method for estimating oestriol, oestrone and oestradiol-17 $\beta$ in human urine. J. Endocrinol. 16: 49.

8. Beling, C. G. 1961. Purification of urinary conjugated oestrogens by gel filtration. Nature (London). 192: 326.

9. Klopper, A., E. A. Michie, and J. B. Brown. 1955. A method for the determination of urinary pregnanediol. J. Endocrinol. 12: 209.

10. Saxena, B. B., H. Demura, H. M. Gandy, and R. E. Peterson. 1968. Radioimmunoassay of human follicle stimulating and luteinizing hormones in plasma. J. Clin. Endocrinol. Metab. 28: 519.

11. Merkatz, I. R., M. I. New, R. E. Peterson, and M. P. Seaman. 1969. Prenatal diagnosis of adrenogenital syndrome by amniocentesis J. Pediat. 75: 977.

12. Romanoff, L. P., C. W. Morris, P. Welch, M. P. Grace, and G. Pincus. 1963. Metabolism of progesterone-4-C $C^{14}$ in young and elderly men. J. Clin. Endocrinol. Metab. 23: 286 .

13. Klopper, A., J. A. Strong, and L. R. Cook. 1957. The excretion of pregnanediol and adrenocortical activity. $J$. Endocrinol. 15: 180.

14. Westphal, U. 1944. Über den Nachweis von Pregnandiolglukuronid im Harn normaler Frauen und Männer. Hoppe-Seyler's Z. Phy'siol. Chem. 281: 14.

15. Bongiovanni, A. M. 1962. The adrenogenital syndrome with deficiency of $3 \beta$-hydroxysteroid dehydrogenase. $J$. Clin. Invest. 41 : 2086.

16. Federman, D. D. 1967. Abnormal Sexual Development; a Genetic and Endocrine Approach to Differential Diagnosis. W. B. Saunders Company, Philadelphia. 119. 
17. Jost, A. 1966. Steroids and sex differentiation of the mammalian foetus. Excerpta Med. Int. Congr. Ser. 132: 74.

18. Prader, A. 1957. Gonadendysgenesie und testikuläre Feminisierung. Schweiz. Med. Wochenschr. 87: 278.

19. Lubs, H. A., Jr., O. Vilar, and D. M. Bergenstal. 1959. Familial male pseudohermaphrodism with labial testes and partial feminization: endocrine studies and genetic aspects. J. Clin. Endocrinol. Metab. 19: 1110.

20. Gilbert-Dreyfus, Savoie, Sébaoun, C. Alexandre, and J. Belaisch. 1957. Etude d'un cas familial d'androgynoidisme avec hypospadias grave, gynécomastie et hyperoéstrogénie. Ann. Endocrinol. 18: 93.

21. Reifenstein, E. C. Jr. 1947. Hereditary familial hypogonadism. Proceedings of the American Federation for Clinical Research. 3: 86. (Abstr.)

22. Jost, A. 1953. Problems of fetal endocrinology: the gonadal and hypophyseal hormones. Recent Progr. Hormone Res. 8: 379.

23. Jost, A. 1954. Hormonal factors in the development of the fetus. Cold Spring Harbor Symp. Quant. Biol. 19: 167.

24. Jost, A. 1958. Embryonic sexual differentiation (morphology, physiology, abnormalities). In Hermaphroditism, Genital Anomalies and Related Endocrine Disorders. H. W. Jones and W. W. Scott, editors. The Williams \& Wilkins Co., Baltimore. 15.

25. Neumann, F., and R. von Berswordt-Wallrabe. 1966. Effects of the androgen antagonist cyproterone acetate on the testicular structure, spermatogenesis and accessory sexual glands of testosterone-treated adult hypophysectomized rats. J. Endocrinol. 35: 363.

26. Stowens, D. 1966. Pediatric Pathology. The Williams \& Wilkins Co., Baltimore. 2nd edition. 686.

27. Greenblatt, R. B., and B. Perez-Ballester. 1969. Gynecomastia. Medical Aspects of Human Sexuality. 3: 52.
28. Bloodworth, J. M. B., editor. 1968. Endocrine Pathology. The Williams \& Wilkins Co., Baltimore. 106.

29. Neumann, F., and W. Elger. 1966. The effect of the antiandrogen 1,2 1 -methylene-6-chloro- $\Delta^{4,8}$-pregnadiene-17 $\alpha$ ol-3,20-dione-17 $\alpha$-acetate (cyproterone acetate) on the development of the mammary glands of male foetal rats. J. Endocrinol. 36: 347.

30. Lawrence, R. D. 1943. Gynaecomastia produced by desoxycorticosterone acetate (DOCA). Brit. Med. J. 1: 12.

31. Prader, A., and G. J. P. A. Anders. 1962. Zur Genetik der kongenitalen Lipoidhyperplasie der Nebennieren. Helv. Paediat. Acta. 17: 285.

32. Prader A., and H. P. Gurtner. 1955. Das syndrom des Pseudohermaphroditismus masculinus bei kongenitaler Nebennierenrinden-Hyperplasia ohne Androgenüberproduktion (adrenaler Pseudohermaphroditismus masculinus). Helv. Paediat. Acta. 10: 397.

33. New, M. I., and R. E. Peterson. 1967. A new form of congenital adrenal hyperplasia. J. Clin. Endocrinol. Metab. 27: 300.

34. New, M. I. 1969. Secretion rates of cortisol and aldosterone precursors in various forms of congenital adrenal hyperplasia. Presented before the International Workshop on The Adrenal Cortex, Aldosterone and Hypertension, sponsored by The Council for High Blood Pressure Research of the American Heart Association, 11 February, Coronado, Calif.

35. Miura, K., K. Yoshinago, K. Goto, I. Katsushima, M. Maebashi, H. Demura, M. Iino, R. Demura, and T. Torikai. 1968. A case of glucocorticoid-responsive hyperaldosteronism. J. Clin. Endocrinol. Metab. 28: 1807.

36. Van Wyk, J. J., and M. M. Grumbach. 1968. Disorders of sex differentiation. In Textbook of Endocrinology. R. H. Williams, editor. W. B. Saunders Company, Philadelphia. 4th edition, 596. 